\title{
Tyrosinase Inhibitory Effects of Saraca Asoca Bark, Leaf and Seed
}

\author{
Perera HKI*, Pradeep APC, Devinda KDU, Ratnayake RMUK and Gunawardhana DKLR \\ Department of Biochemistry, University of Peradeniya, Sri Lanka
}

Submission: November 15, 2017; Published: December 11, 2017

*Corresponding author: Handunge Kumudu Irani Perera, Department of Biochemistry, University of Peradeniya, Sri Lanka, Fax: $94-81$ 238 9106; Tel: 94-81 239 6321; Email: kumudup@pdn.ac.lk

\begin{abstract}
Abnormal deposition of melanin in the skin has great impact on cosmetics and has prompted development of agents that could interfere with melanin synthesis. As the regulatory enzyme of melanogenic pathway, tyrosinase has become a major target for the control of skin pigmentation. Toxic effects of chemically derived whitening compounds used in cosmetics led to the search for alternative agents form medicinal plants to control skin hyperpigmentation. The objective of this study was to assess in vitro tyrosinase inhibitory effects of Saraca asoca bark, leaf and seed.

Methanol extracts of Saraca asoca (Ashoka) (SA) bark, leaves and seeds were prepared. Tyrosinase from mushroom was pre-incubated with phosphate buffer ( $\mathrm{pH} 6.5$ ) and SA extracts for $10 \mathrm{~min}$ at $25{ }^{\circ} \mathrm{C}$. Respective control was prepared in the absence of extracts and the blanks were prepared without tyrosinase. Substrate 3,4-Dihydroxy-L-phenylalanine (L-DOPA) was added and incubated for $10 \mathrm{~min}$ at $25{ }^{0} \mathrm{C}$. Absorbance was read at $475 \mathrm{~nm}$. Kojic acid was used as the standard inhibitor.

All three AS extracts showed in vitro inhibitory effects between 73.58 and $91.86 \%$ at $0.5 \mathrm{mg} / \mathrm{mL}$ against tyrosinase. IC ${ }_{50}$ values of bark, leaf and seed extracts were $75.5,53.5$ and $54.2 \mu \mathrm{g} / \mathrm{mL}$ respectively. A dose dependent increase in the inhibitory activity was observed in all three extracts with a more pronounced increase with the leaf extracts.
\end{abstract}

Keywords: Saraca asoca; Tyrosinase; Skin lightening

\section{Introduction}

Melanin plays a crucial role in protecting the skin from free radicals and various types of ionizing radiations, including UV radiation [1]. However, formation of increased amount of melanin results in dermatological disorders such as melasma, freckles and age spots [2]. Abnormal melanin deposition in the skin has great impact on cosmetics and has prompted research and development of agents that could interfere with melanin synthesis [3].

Melanin is synthesized in epidermal melanocytes through a series of oxidative reactions within a specialized organelle called melanosomes [4]. Melanogenesis is mediated by a series of enzyme catalyzed reactions which is initiated with the enzyme tyrosinase. Tyrosinase catalyzes hydroxylation of tyrosine to 3,4-dihydroxyphenylalanine (L-DOPA) by monophenolase action and oxidation of DOPA to DOPA-quinone by diphenolase action [5]. First step catalysed by tyrosinase is the rate-limiting step and the remainder of the reaction sequence proceeds spontaneously [4].
As the regulatory enzyme of melanogenic pathway, tyrosinase has become a major target for the control of skin pigmentation [3]. Therefore tyrosinase inhibitors can be clinically useful for the treatment of dermatologic disorders associated with melanin hyperpigmentation and applications in cosmetic products for skin whitening [6]. In spite of the potentially toxic health effects, skin bleaching (lightening using chemicals) is a widespread fact which is more frequently used to lighten the skin complexion [7]. Toxic effects of chemically derived whitening compounds used in cosmetics led to the search for alternative herbal and pharmaceutical agents to treat skin hyperpigmentation.

Medicinal herbs that are used for a healthy and radiant skin are described as varnya drugs in Ayurveda [8]. There are more than 200 medicinal plants that are used to maintain and enhance the beauty of the skin [8].

Saraca asoca (Roxb.) De.wild or Saraca indica is a medium sized evergreen tree that belongs to the subfamily Caesalpinaceae of legume family [9]. Saraca asoca (SA) is known as Ashoka meaning "without sorrow" in Sanskrit. SA root is used 
to treat skin diseases such as eczema, psoriasis, dermatitis, freckles and pruritis. It is also used in external inflammations, ulcers, scabies and Tinea pedis. SA is used as a paste, wash or a cream to relieve these disorders [9]. Furthermore SA is used to revitalize the complexion and skin tone [9]. SA bark is used in several gynecological disorders and is a main ingredient in several ayurvedic preparations such as ashokarista [10]. However, investigations carried out regarding the effects of SA on potential skin lightening effects are lacking.

The objective of this study was to assess in vitro tyrosinase inhibitory effects of Saraca asoca bark, leaf and seed.

\section{Materials and Methods}

\section{Plant Material}

Saraca asoca bark leaves and seeds were collected from Peradeniya, Sri Lanka and authenticated by the Deputy Director, National Herbarium, Royal Botanical Garden, Peradeniya. Plant materials were cleaned dried under shade for one week and powdered using a grinder. Methanol extracts were prepared using a sonicator and the methanol was evaporated at a temperature below $45{ }^{\circ} \mathrm{C}$ using a rotary evaporator. Dry extracts were stored at room temperature. Bark and seed extracts were dissolved in phosphate buffer ( $\mathrm{pH}$ 6.5) immediately before the assay to prepare $10 \mathrm{mg} / \mathrm{mL}$ working solutions. Leaf extracts were dissolved in DMSO at initial concentration of $100 \mathrm{mg} / \mathrm{mL}$ and then diluted to $10 \mathrm{mg} / \mathrm{mL}$ with phosphate buffer.

\section{Measurement of tyrosinase activity}

Tyrosinase activity of the test samples were measured with the method of Vaibhav and Lakshaman with modifications [11]. Tyrosinase from mushroom $(31.25 \mathrm{U} / \mathrm{mL})$ was pre-incubated with phosphate buffer $(0.05 \mathrm{M}, \mathrm{pH} 6.5)$ and plant extracts $(0.5 \mathrm{mg} / \mathrm{mL})$ for $10 \mathrm{~min}$ at $25{ }^{\circ} \mathrm{C}$. Respective control was prepared in the absence of extracts and the blanks were prepared without tyrosinase. Then the substrate 3,4-Dihydroxy-L-phenylalanine (L-DOPA) was added $(0.355 \mathrm{mM})$ and incubated for $10 \mathrm{~min}$ at 25 ${ }^{0} \mathrm{C}$. Total volume of the reaction mixture was $1 \mathrm{~mL}$. Immediately after 10 min incubation, absorbance was read at $475 \mathrm{~nm}$. Kojic acid was used as the standard inhibitor. Each measurement was taken in duplicate and on three separate occasions.

Inhibitory effects on tyrosinase activity were calculated using the following formula. $\mathrm{IC}_{50}$ values of the extracts were measured using the extract concentrations in the reaction between 15 and $275 \mu \mathrm{g} / \mathrm{mL}$.

Percentage inhibitory effect of tyrosinase $=\frac{(\text { Control }- \text { Control blank })-(\text { Test }- \text { Test blank }) \times 100}{(\text { Control }- \text { Control blank })}$

\section{Statistical analysis}

Means and standard deviations were calculated using measurements taken on three separate occasions. Statistical significance of the differences was calculated using ANOVA. $\mathrm{P}<0.05$ was considered as statistically significant.

\section{Results}

All three AS extracts showed inhibitory effects against tyrosinase with $\mathrm{IC}_{50}$ values ranging from 53.5 to $75.5 \mu \mathrm{g} / \mathrm{mL}$ (Table 1). Kojic acid showed a significantly higher $(\mathrm{p}<0.0007)$ inhibitory effect with $\mathrm{IC}_{50}$ value of $3.4 \mu \mathrm{g} / \mathrm{mL}$ (Table 1 ). A dose dependent increase in the inhibitory activity was observed in all three extracts. However, the degree of the increase in the inhibitory effects was more pronounced with the leaf extracts (Figure 1).

Table 1: Tyrosinase inhibitory effects of extracts.

\begin{tabular}{|c|c|c|}
\hline Plant Part & Mean \pm SD & IC $_{\mathbf{5 0}}(\boldsymbol{\mu g} / \mathbf{m L})$ \\
\hline AS bark & $73.58^{*} \pm 3.26$ & 75.5 \\
\hline AS leaves & $91.86^{*} \pm 2.87$ & 53.5 \\
\hline AS Seed & $83.27^{*} \pm 0.83$ & 54.2 \\
\hline Kojic acid & & $3.4^{* *}$ \\
\hline
\end{tabular}

*Mean inhibitory effects of three SA extract at $0.5 \mathrm{mg} / \mathrm{mL}$ were significantly different $(p<0.002$ to 0.03$)$.

** $\mathrm{IC}_{50}$ of Kojic acid was significantly lower than that of AS extracts $(p<0.0007)$.

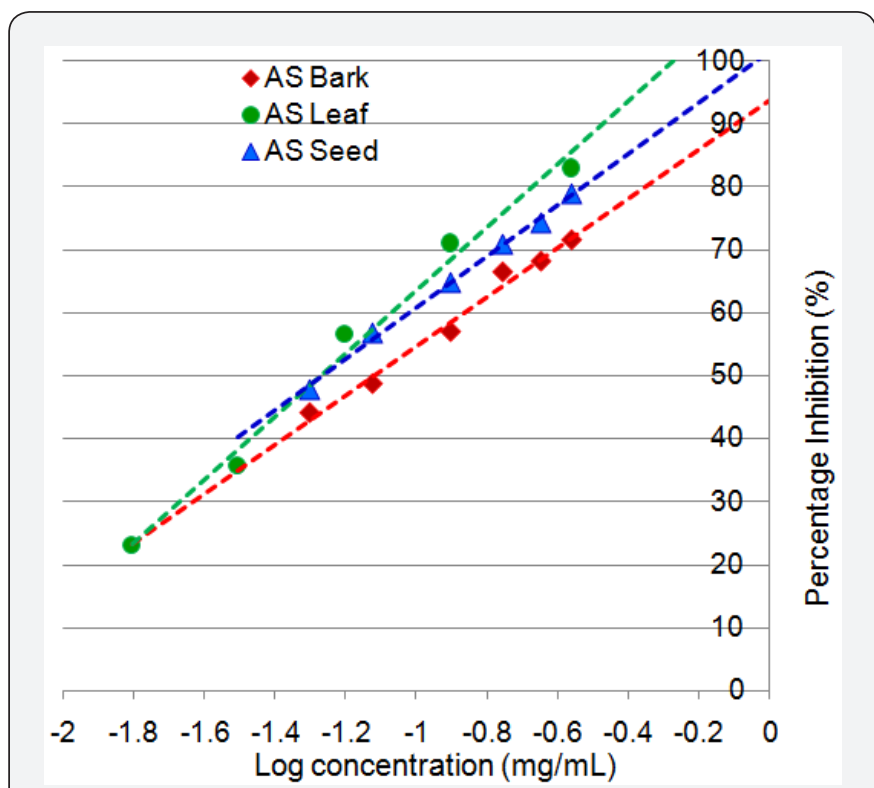

Figure 1: Tyrosinase inhibitory effects of extracts at different concentrations.

\section{Discussion}

SA is used to treat various skin disorders and to beautify the skin. However, reports on analysis of skin lightening effects of SA are not available according to up to date literature search. In this study the evidence on the possible skin lightening effects of three parts of SA were revealed as all three parts investigated namely, bark, leaf and seed demonstrated promising inhibitory effects on tyrosinase. Polyphenols are considered as the largest group of natural compounds acting as tyrosinase inhibitors [12]. 
Depending on the structure, several polyphenols are reported to act as substrates for tyrosinase. Polyphenolic compounds such as catechin, epicatechin, $\beta$-sitosterol, gallic acid and quercetin have been identified from SA plant. Among the compounds identified from SA bark, epicatechin and gallic acid are the major polyphenolic compounds which have demonstrated various pharmacological effects [13].

Scientific validation of various other beneficial effects of parts of SA is available which are applicable to skin. Antioxidant effects [14], antibacterial and antifungal effects [15] and antiinflammatory effects [16] of methanol extracts of SA bark have been reported. Methanol extracts of leaf also has demonstrated antibacterial effects [16]. Furthermore, hepatoprotective effects of methanol extracts of SA bark against $\mathrm{CCl}_{4}$ toxicity has been reported [17].

\section{Conclusion}

Promising inhibitory effects of methanol extracts of SA bark, leaf and seed on tyrosinase were revealed. Hence, the current study provides evidence to validate the use of AS to promote the beauty and health of skin. Further studies are necessary to investigate the efficacy and safety of SA extracts in vivo.

\section{References}

1. Solano F (2014) Melanins: Skin pigments and much more-Types, structural models, biological functions, and formation routes. New J Sci 2014(2014): 1-28.

2. Zhang H, Zhou Q (2013) Tyrosinase inhibitory effects and antioxidative activities of saponins from Xanthoceras sorbifolia nutshell. PLoS One 8(8): e70090.

3. Matsuda H, Murata K, Itoh K, Masuda M, Naruto S, et al. (2011) Melanin hyperpigmentation inhibitors from natural resources. Adv Malig Melanoma -Clin Res Perspect 2011: 171-184.

4. Cichorek M, Wachulska M, Stasiewicz A, Tymiska A (2013) Skin melanocytes: Biology and development. Postepy Dermatol Alergol
30(1): 30-41.

5. Videira IF, Moura DF, Magina S (2013), Mechanisms regulating melanogenesis. An Bras Dermatol 88(1): 76-83.

6. Wu B (2014) Tyrosinase inhibitors from terrestrial and marine resources. Curr Top Med Chem 14(12): 1425-1449.

7. Darj E, Infanti JJ, Ahlberg BM, Okumu J (2015) The fairer the better? Use of potentially toxic skin bleaching products. Afr Health Sci 15(4): 1074-1080.

8. Matsuura R, Ukeda H, Sawamura M (2006) Tyrosinase inhibitory activity of citrus essential oils. J Agric Food Chem 54(6): 2309-2313.

9. Pradhan P, Joseph L, Gupta V, Chulet R, Arya H, et al. (2009) Saraca asoca (Ashoka): A Review. J Chem Pharm Res 1(1): 62-71.

10. Bhat P, Hegde GR, Hegde G, Mulgund G (2014) Ethnomedicinal plants to cure skin diseases-an account of the traditional knowledge in the coastal parts of Central Western Ghats, Karnataka, India. J Ethnopharmacol 151(1): 493-502.

11. Vaibhav S, Lakshaman K (2012) Tyrosinase Enzyme Inhibitory Activity of selected Indian Herbs. Int J Res Pharm Biomed Sci 3(3): 977-982.

12. Chang TS (2009) An updated review of tyrosinase inhibitors. Int J Mol Sci 10(6): 2440-2475.

13. Ahmad F, Misra L, Tewari R, Gupta, Mishra P, et al. (2016) Antiinflammatory flavanol glycosides from Saraca asoca bark. Nat Prod Res 30(4): 489-492.

14. Reingold EM, Charness N, Pomplun M, Stampe DM (2001) Phytochemical analysis of Saraca asoka bark extracts. Psychol Sci 321: 48-55.

15. Sainath RS, Prathiba J, Malathi R (2009) Antimicrobial properties of the stem bark of Saraca indica (Caesalpiniaceae). Eur Rev Med Pharmacol Sci 13(5): 371-374.

16. Sarojini N, Manjari SA, Kanthi CC (2011) Phytochemical screening and antibacterial activity study of Saraca indica leaves extract. Int Res J Pharm 2(7): 176-179.

17. Arora B, Choudhary M, Arya P, Kumar S, Nitesh Choudhary, et al. (2015) Hepatoprotective potential of Saraca ashoka (Roxb.) De Wilde bark by carbon tetrachloride induced liver damage in rats. Bull Fac Pharmacy, Cairo Univ 53(1): 23-28.

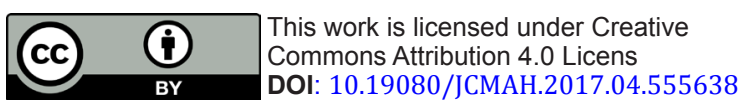

